\title{
Factors that Affecting Female Nurse Performance with Work Stress as an Intervening Variable in the Hospital of Dr. Tadjuddin Chalid Makassar
}

\author{
Magfirah Ramadhani $^{1 \star}$, Masyitha Muis ${ }^{1}$, Yahya Thamrin ${ }^{1}$ (D) M. Furqaan Naiem ${ }^{1}$, Indar Indar ${ }^{2}$, Wahiduddn Wahiduddn ${ }^{3}$ (D) \\ ${ }^{1}$ Department of Occupational Safety and Health, Universitas Hasanuddin, Makassar, Indonesia; ${ }^{2}$ Department of Health \\ Administration and Policy, Universitas Hasanuddin, Makassar, Indonesia; ${ }^{3}$ Department of Epidemiology, Universitas \\ Hasanuddin, Makassar, Indonesia
}

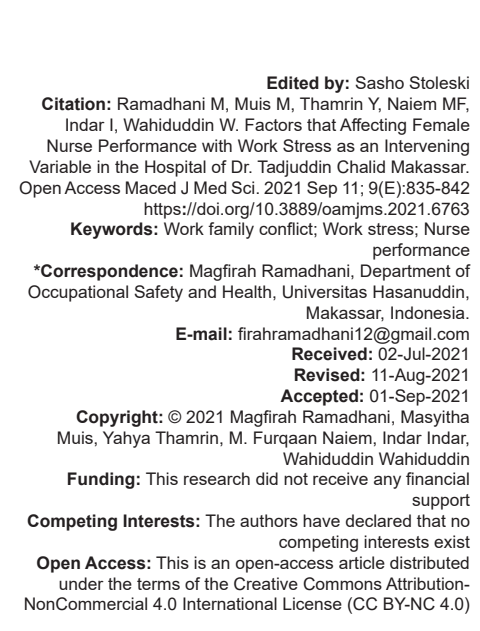

\section{Introduction}

Nurse performance is the productivity of nurses in providing nursing care according to their authority and responsibility which can be measured in quality and quantity. Nurse performance is a measure of success in achieving nursing service goals. Female nurse who have been married is a female who have multiple role multiple role is two or more roles that run concurrently which experience the conflict. This conflict causes many problems that affect family life and female's job that causes work family conflict (WFC) [1].

Nurses are one of the jobs that provide services in hospitals for $24 \mathrm{~h}$ so that nurses are needed who are willing to work with the shift method. Shift work is professional practice standard method that could not be ignored for many nurses and must be carried out with full responsibility [2]. $12 \mathrm{~h}$ shift rotation is commonly used in the whole world; however, there are worries about the effect of nursing quality and patient safety [2], [3]. Most of nurse who work night shift experience safety problem to patient (85.7\%), and effect to physiology consequence $(93.6 \%)$ [4]. The negative impact of night shift work could effect worker health, especially cause fatigue, drowsiness, mood, and weight gain [5], [6], [41]. Have been reported that some health risks that can happen, include the increase of metabolic syndrome, low sleep quality, and sleep time that is not enough [7], [8].

Nurse professional job, long-term rhythm of life that is not regular and the pressure of much life aspect cause sleep problem, affect the efficiency and nursing work quality [9]. The related study as many as $58.4 \%$ female nurse and $38 \%$ male nurse experience sleep 
disturbance [10]. The result of research was conducted by Zurlo et al. explained that female nurse felt the level of WFC that is significantly higher, anxiety, depression, and somatization. WFC as significantly related to anxiety and depression in male nurse and somatization in both gender [11]. This bad eating behavior contributes to their overweight status. A study by Nuhu et al. (2020) has been reported that junior nurse staffs who have more working hours recorded the highest stress number who is experienced compared to nurses who have [12].

The quality of nurse sleep have not been optimal, only $30.7 \%$ nurses who have good sleep quality based on the research, the status of nurses sleep are worse than general population [5], [13], [14] We suppose that the possible reason is shift does not break, overtime, the highest work intensity that is paired with the salary level that is relatively low, the alert system prevent off day that is utilized completely [15], [16], [17]. A study explore sleep quality impact, include the effect of working, safety, psychology, and the other aspects [18]. The quality of sleep that is worst, it would make a depression and lack of attention in their working everyday. The sleep problem would decrease their personal identity feeling [19].

Masyitha Muis et al. (2021) stated that frustration feeling impact on work stress that is something that is experienced by employee where imbalance between psychological and physics that can affect the process and employee condition so that can affect on company performance [20]. According to American Psychological Association survey in 2019, more than three quarters adult reported the stress symptom, include the alteration of sleep habit from the obtained data showed that the stress level of GRPeople will affect on sleep quality. This thing can be seen on the result of research that showed the respondent that is no stress consist of 11 respondents (84.6\%) have a good sleep quality and two respondents (15.4\%) have a bad sleep quality. In light stress, it was obtained that 25 respondents $(67.6 \%)$ have a good sleep quality and 12 respondents $(32.4 \%)$ have a bad sleep quality. In moderate stress, it is obtained 2 respondents $(5.6 \%)$ have a good sleep quality and 34 respondents (94.4\%) have bad sleep quality and in heavy stress, it is obtained ten respondents (100\%) have bad sleep quality.

Based on the first data obtained, the result of previous research that was conducted by Diah at Hospital. Dr. Tadjuddin Chalid Makassar obtained female nurses that were experienced WFC with high category as many as 61 people (63.5\%), experience work stress with high category as many as 77 people $(80.2 \%)$. Moreover, it is obtained result that there is no direct and indirect effect of WFC on performance through work stress as intervening variable [21]. Based on the background explanation above, the researcher will continue the related study and to find out more about factor that affect on female nurse performance at Makassar Dr. Tadjuddin Chalid Hospital.
The aim of the study was to analyze direct and indirect effect of work family conflict, shift work, nutrition status, sleep quality of nurses' performance through work stress as intervening variable on female nurses in Makassar Dr. Tadjuddin Chalid Hospital.

\section{Design and Methods}

\section{Types and research design}

The types of this research used observational analytical with cross-sectional design. This research was conducted in February - June 2021 at Dr. Hospital. Tadjuddin Chalid Makassar. The population in this study was all married female nurses at Dr. Hospital. Tadjuddin Chalid Makassar, totaling 90 people. The number of research samples is 73 people.

\section{The instrument of data collection}

\section{Primary data}

The primary data obtained by female nurses who work in Hospital of Dr. Tadjuddin Chalid Makassar, with give questionnaire directly that is filled by respondents who fulfill the criteria based on the purpose of this study. The questionnaire of WFC is maked tose work family conflict scale. The instrument used for quality of sleep was Pittsburg Sleep Quality Index (PSQI). PSQI reflected sleep quality from someone in the last month. The instrument used for work stress was instrument that was surveyed by work stress questionnaire from American Institute of Stress in differential semantic scale. The instrument used for performance was questionnaire of performance from Mathis and Jackson (2006) in Likert scale. This scale includes quantity, quality, timeliness of result, the effectivity, and presence.

Table 1 shows that the question item with an $r$ value that is greater than the r-table of 0.296 is a feasible question and can be used for research purposes. The Cronbach's Alpha value which is $>0.6$ indicates that all of the question items contained in the questionnaire are reliable in accordance with the reliability test.

\section{The secondary data}

The secondary data obtained at hospital administration room include the number of nurse, work period of nurse, work duration of female nurses who is registered to facilitate sample adequacy estimate.

\section{The analysis of data}

Data analysis used univariate analysis that is used for each variable, from the result of research with used frequency distribution table and the percentage of variable in using SPSS program version 24 and 
Table 1: Validity and reliability of the instrument

\begin{tabular}{|c|c|c|c|}
\hline Variable & Item & $r$ & Alpha Cronbach \\
\hline \multirow[t]{10}{*}{$\overline{\text { WFC }}$} & $\mathrm{X} 1$ & 0.793 & 0.699 \\
\hline & $\mathrm{X} 2$ & 0.844 & \\
\hline & X3 & 0.878 & \\
\hline & $\mathrm{X} 4$ & 0.844 & \\
\hline & $\times 5$ & 0.492 & \\
\hline & $\mathrm{X} 6$ & 0.754 & \\
\hline & $\mathrm{X} 7$ & 0.806 & \\
\hline & $\mathrm{X} 8$ & 0.825 & \\
\hline & $\times 9$ & 0.777 & \\
\hline & $\mathrm{X} 10$ & 0.686 & \\
\hline \multirow[t]{15}{*}{ Sleep quality } & $\mathrm{X} 1$ & 0.731 & 0.806 \\
\hline & $\mathrm{X} 2$ & 0.608 & \\
\hline & X3 & 0.723 & \\
\hline & $\mathrm{X} 4$ & 0.440 & \\
\hline & $\times 5$ & 0 & \\
\hline & $\mathrm{X} 6$ & 0.472 & \\
\hline & $\mathrm{X} 7$ & 0.596 & \\
\hline & $\mathrm{X} 8$ & 0.572 & \\
\hline & X9 & 0.324 & \\
\hline & $\mathrm{X} 10$ & 0.543 & \\
\hline & X11 & 0.797 & \\
\hline & $\mathrm{X} 12$ & 0 & \\
\hline & $\mathrm{X} 13$ & 0.490 & \\
\hline & $\mathrm{X} 14$ & 0.476 & \\
\hline & X15 & 0 & \\
\hline \multirow[t]{8}{*}{ Work stress } & $\mathrm{X} 1$ & 0.710 & 0.899 \\
\hline & $\mathrm{X} 2$ & 0.749 & \\
\hline & $\mathrm{X} 3$ & 0.809 & \\
\hline & $\mathrm{X} 4$ & 0.801 & \\
\hline & $\times 5$ & 0.833 & \\
\hline & $\mathrm{X} 6$ & 0.819 & \\
\hline & $\mathrm{X} 7$ & 0.822 & \\
\hline & X8 & 0.697 & \\
\hline \multirow{10}{*}{ Nurse performance } & $\mathrm{X} 1$ & 0.790 & 0.909 \\
\hline & $\times 2$ & 0.666 & \\
\hline & $\mathrm{X} 3$ & 0.810 & \\
\hline & $\mathrm{X} 4$ & 0.889 & \\
\hline & $\times 5$ & 0.841 & \\
\hline & $\mathrm{X} 6$ & 0.790 & \\
\hline & $\mathrm{X} 7$ & 0.934 & \\
\hline & $\mathrm{X} 8$ & 0.722 & \\
\hline & $\times 9$ & 0.497 & \\
\hline & $\mathrm{X} 10$ & 0.533 & \\
\hline
\end{tabular}

multivariate analysis used to know the effect of two or more variables or direct effect and indirect effect with handle the another variable and to know how big is the influence of variable purely with used Path Analysis with SmartPLS program.

\section{Results}

Table 2 showed that the most age range of respondents were 31-40 years as many as 25 respondents $(34.3 \%)$ and the least age of respondents were $51-60$ years as many as ten respondents (13.7\%) Based on the last education of respondents, the most last education of respondents were bachelor as many as 46 respondents (63\%) and the least last education of the respondents were Vocational High School as many as one respondent (1.4\%). Based on work period of respondent, the most work period of respondents were $>10$ years as many as 46 respondent's (63\%) and the least work period of respondents were 27 respondents (36.99\%). Based on work duration of respondent, the most work duration were $8 \mathrm{~h}$ as many as 67 respondents (91.8\%), and the least work duration were $>8 \mathrm{~h}$ as many as 6 respondents $(8.2 \%)$. Based on the number of children of respondents, the most
Table 2: Characteristics of female nurse in Makassar Dr. Tadjuddin Chalid Hospital

\begin{tabular}{lll}
\hline Variable & $\mathrm{n}$ & $\%$ \\
\hline Age & & \\
$21-30$ years & 16 & 21.92 \\
$31-40$ years & 25 & 34.25 \\
$41-50$ years & 22 & 30.14 \\
$51-60$ years & 10 & 13.70 \\
Education & & \\
Diploma & 24 & 32.88 \\
Bachelor & 46 & 63.01 \\
Magister & 2 & 2.74 \\
Vocational high school & 1 & 1.37 \\
Work period & & \\
$<10$ years & 27 & 36.99 \\
$\geq 10$ years & 46 & 63.01 \\
Work duration & & \\
$8 \mathrm{~h}$ & 67 & 91.78 \\
$>8 \mathrm{~h}$ & 6 & 8.22 \\
The number of children & & 13.70 \\
0 & 10 & 19.18 \\
1 & 14 & 26.03 \\
2 & 19 & 27.40 \\
3 & 20 & 8.22 \\
4 & 6 & 1.37 \\
5 & 1 & 4.11 \\
6 & 3 & 2.74 \\
Having housekeeper & & 97.26 \\
Yes & 2 & 100 \\
No & 71 & \\
Total & 73 & \\
\hline
\end{tabular}

number of children of respondents were three children as many as 20 respondents $(27.4 \%)$, and the least number of children were five children as many as one respondent (1.4\%). Based on housekeeper distribution, as many as 71 respondents $(97.3 \%)$ did not have housekeeper and as many as twi respondents $(2.7 \%)$ have housekeeper Based on shift work, the most shift work were morning shift as many as 47 respondents (64.4\%) and the least shift work were night shift as many as eight respondents (11\%).

Based on Table 3, the variable of research showed that from 73 female nurse respondents in Makassar Dr. Tadjuddin Chalid Hospital who were married and taken as respondent, on WFC most of respondents experience WFC with low category as many as 58 respondents $(79.5 \%)$, the most shift work were morning shift as many as 47 respondents (57.3\%), for the most nutrition status were nutrition status with normal category as many as 45 respondents $(61.6 \%)$, the most quality of sleep as many as sleep quality with bad category as many as 40 respondents (54.8\%), the most work stress were work stress with low category as many as 38 respondents (52.1\%) and the most nurse performance were good performance category as many as 61 respondents (83.6\%).

Figure 1 shows the effect of WFC (X1) on performance (Y2). With statistical tests, the results obtained from the p-value $(0.462)>0.05$ with an estimate value of 0.736 , which means that the $p$-value is more than the 0.05 significance level, so there is no direct effect of WFC on performance. The effect of WFC (X1) on work stress (Y1), with a statistical test the results obtained from the $p$-value $(0.001)<0.05$ with an estimate value of 3.193 which means the $\mathrm{p}$-value is $<0.05$ significance level so that there is a direct effect of WFC to work stress. The effect of work stress (Y1) on performance (Y2), with a statistical test 
Table 3: Distribution of female nurse in hospital of Dr. Tadjuddin Chalid Makassar

\begin{tabular}{lll}
\hline Variable & $\mathrm{n}$ & $\%$ \\
\hline WFC & 15 & 20.5 \\
$\quad$ The high WFC & 58 & 79.5 \\
$\quad$ The low WFC & & \\
Shift work & 47 & 64.4 \\
$\quad$ Morning & 18 & 24.7 \\
$\quad$ Noon & 8 & 11 \\
$\quad$ Night & & \\
Nutrition status & 28 & 38.4 \\
$\quad$ No normal (if BMI <18.5 and >25.00) & 45 & 61.6 \\
$\quad$ Normal (if BMI 18.5-24.99) & & \\
Sleep quality & 40 & 54.8 \\
$\quad$ Bad & 33 & 45.2 \\
$\quad$ Good & & 47.9 \\
Work stress & 35 & 52.1 \\
$\quad$ High & 38 & 16.4 \\
$\quad$ Low & & 83.6 \\
Nurse performance & 12 & 100 \\
$\quad$ Bad & 61 & \\
$\quad$ Good & 73 & \\
$\quad$ Total & & \\
WFC: Work family conflict, BMl: Body mass index. &
\end{tabular}

the results obtained from $p$-value $(0.003)<0.05$ with an estimate value of 3.022 which means the $p$-value is less than the level of influence of nutritional status (X3) on performance (Y2), where from the statistical test results obtained from the $p$ value $(0.166)>0.05$ with an estimate value of 1.27 which means the $p$ value is more than the 0.05 significance level so that there is no direct influence of nutritional status on performance.

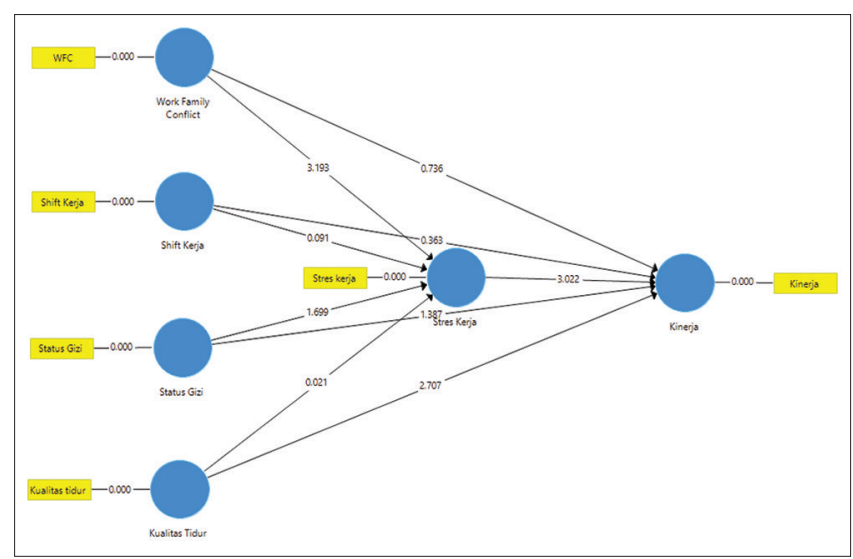

Figure 1: Path analysis

The effect of nutritional status (X3) on work stress (Y1), where from the statistical test results obtained from the p-value $(0.090)>0.05$ with an estimate value of 1.699 which means the $p$-value is more than the 0.05 significance level so that there is no direct effect nutritional status on work stress. The effect of sleep quality (X4) on performance (Y2), where from the statistical test results obtained from the $p$-value $(0.007)<0.05$ with an estimate value of 2.707 which means the $p$-value is $<0.05$ significance level so that there is a direct influence on sleep quality on performance. The effect of sleep quality (X4) on work stress (Y1), where from the statistical test results obtained from the p-value $(0.983)>0.05$ with an estimate value of 0.021 which means the $p$-value is more than the 0.05 significance level so that there is no effect direct sleep quality to work stress.

\section{Discussion}

\section{The effect of WFC on performance through work stress as intervening variable}

This research showed that WFC does not have direct effect on nurses performance in Hospital of Dr Tadjuddin Chalid Makassar. This caused by female nurses can divide their time between family and job, besides, female nurses also have responsibility in work place and have a commitment to finish their job based on standard that have been given by Hospital. WFC is conflict that happens when energy, time, or behavior demands of someone contrary with family role or personal life. WFC is also said as conflict that happen when family disturb job. The main assumption of WFC is demand and job hope (for instance: Work overtime, and travelling) often contradict with family demand (for instance: to pick up kids from school) when individual multiple role such as job and family are not suitable each other, that is called conflict [22].

Female nurse prioritize job problem that relates on work hour, job as nurses and try to give a good service on patient. Based on the research was conducted by Diah, She said that Although female nurse experience WFC, nurses keep run their job as usual such as present on time, never skipping when they work and able to service patient and can work with the other nurse although unsettled mood Much pressure that is faced by nurse especially pressure in family, it does not make nurse feel unburdened until nurse can run the task that is given [21].

Although WFC does not effect directly on performance, but WFC has direct effect on work stress, then work stress also has direct effect on female nurse performance in Hospital of Tadjuddin Chalid Makassar. This is caused by work stress is responds that are have by someone when is faced with demand and job pressure that is not suitable with their knowledge and ability, and pressure that is felt by every individual such positive or negative pressure. When WFC happens on someone, then health and prosperity are destructed by the accumulation of pressure of home and job itself, until imbalance happen and cause constant fatigue, easy angry, inability in developing until can cause high work stress that will cause dissatisfaction with job, cause absentism and physics and mental disorder [23].

This approved by Kharis research, he said that nurse that experience WFC can improve work stress. Besides, the lack of family togetherness and there is conflict between commitment and responsibility on family became the major reason of nurse experience WFC. The lack of togetherness in family make relationship between nurse and family become less harmonious until make nurse experience work stress [24]. 


\section{The effect of shift work on performance through work stress as a intervening variable}

Shift work is determination of working hours that occurs once in $24 \mathrm{~h}$ (1 day). Based on regulation concerning manpower, it has been specifically regulated in articles 77-85 of Law No.13 of 2003. This research showed that shift work does not has direct effect on performance and shift work also does not has direct effect on work stress, but work stress has direct effect on performance. Thus, it can be conclude that there is no direct and indirect effect of shift work on performance although through work stress as intervening variable on nurse in Hospital of Dr Tadjuddin Chalid Makassar. This caused by female nurse who become respondent on this research is major of morning shift work consist of 47 respondents. Morning shift starts from 08.00 am - 14.00 pm. Shift work does not affect on female nurse performance because shift work in Hospital of Dr Tadjuddin Chalid Makassar has suitable with standard that has been set.

The result of related studies was conducted by Seguh et al. used relationship test between shift work between nurse performance in impatient room of General Hospital of Bhayangkara Level III Manado with used chi square correlation test that showed there is no relation between shift work with nurse performance. This caused by shift work that applied by Hospital of Bhayangkara Level III Manado has already regular and most of nurse who in impatient room follow shift work schedule based on schedule that has already decided until respondent are not at risk of experiencing a decrease in work. Shift work that is followed based on schedule; it helps nurse in doing their job [25].

Besides, the respond of nurse that is surveyed showed that they care about their health when involved with night shift and find out that keep active and alert are nurse attention who are least. The finding of this research is consistent with other research that nurse who involved with night shift faced things that can cause less of sleep, musculoskeletal disorder, stress, eat that is bad and other sistemic effect [26], [27], [28]. Overall, over of $93.6 \%$ participants reported to experience physiologic effect of night shift work [29], [5].

\section{The effect of nutrition status on performance through work stress as intervening variable}

Nutrition status of adult especially that related to underweight and overweight. Less ideal weight is malnutrition and overnutrition can cause problem on body health. Malnutrition and overnutrition problem on adult (age $>18$ years) is important thing because apart from risk of certain disease, also can affect productivity and someone performance. Nutrition status in this research is normal or no normal gizi condition on worker measured based on body mass index (BMI) Someone is said to have normal nutrition status if result of BMI measurement $18.5-25.0$ and is said is no normal if result of BMI measurement $<18.5$ or $>25.0$.

The research showed that nutrition status does not have direct effect on performance and nutrition status does not have direct effect on work stress, but work stress has direct effect on performance. Thus, it can be concluded that there is no direct and indirect effect of nutrition status on performance although it through work stress as intervening variable on nurse in Hospital of Dr Tadjuddin Chalid Makassar.

This cause based on the distribution of respondent nutrition status has more normal nutrition status consist of 45 respondents. The research showed that more nurses have already developed eating behavior that is health with BMls that are normal. Most of nurse have normal nutrition status, nurse can handle work stress with set dietary habit that is health and nutritious.

This research related to Yamin et al. research said that BMI does not have relation with performance in Hospital of Sawerigading Palopo. The research was conducted by Hergenroeder, Andrea et al. showed that performance based measurement, individual who is obesity has running speed is slower than weight group [34]. Liniar regression analysis showed that BMI dilute self-report and physics function measurement based on performance. Job Demand that increasing can be solved with good nutrition status. A good nutrition status then nurse can do their job effectively and efficiency but if there is malnutrition on food that is consumed by nurse will effect on not achieved efficiency and work productivity that is optimal because self-defense on decreasing disease, reduced physical ability, weight loss, less enthusiastic, less motivation, react sluggish, and aphatetic [30].

The research was conducted by Nuhu et al., 2020 rate the relationship between calorie intake and stress relate to job between in two district hospitals The result of research showed that nurse in developing eating behavior that is no healthy that is marked with calorie intake that is bad on job time that is different in effort to adjust and adopt stress in job place, is approved with BMI that is height and stress level that is noted [12].

Low calorie intake in job place also parallel with finding that is acut stress, such as experienced by emergency patient is running to hospital cause physiology responds that push appetite. Thus, it can be conclude that the increasing of stress and depression level in nurse in running their job can affect body system, until their nutrition status. Mehlum also report appetite suppression by corticotropin-releasing hormone during stress. This thing can be related to submission Björntorp et al. stated that cortisol as marker of activity of the hypothalamic-pituitary-adrenal axis, can affect appetite through neuropeptide $Y$ and leptin. Average level of saliva cortisol that is measured both when on duty and not on duty showed that saliva cortisol as physiological; 
stress indicator will increase with the increasing of stress level. Cortisol levels rise due to disturbances in the organism's environment [31], [32].

Muscle contraction occurs when body moves using adhenosine triphosphate (ATP) and calcium energy $>$ When ATP is used by muscle to contract will directed by anaerobic metabolism is fuel without oxygen metabolism, then fuel damage is no optimal and lactat acid is formed. The accumulation of lactate acid responsible for muscle complaints. If muscle keep contraction, there is no chance to relaxation, then there is muscle complaints. then, general effect of stress on body include muscle ache, chest pain, increased hearth rate, and blood pressure, weakened body system and can affect mood, hypersensitive, and affect the ability to think types to focus on job [23].

\section{The effect of quality of sleep on performance through work stress as intervening variable}

The quality of sleep is comprehensive index to evaluate sleep effectivity. The quality of sleep is combination of objective evaluation (sleep time, get up time, etc.) and subjective evaluation (sleep difficulties, rest level, etc.). Based on the result of sleep quality has direct effect on performance, but sleep quality does not have direct effect on work stress, while work stress has direct effect on performance. Thus, it can be conclude that there is direct effect of sleep quality on performance but there is no indirect effect of sleep quality on performance through work stress as intervening variable on nurse in Hospital of Dr Tadjuddin Chalid Makassar.

Sleep quality affect directly on nurse performance, this caused by most of nurse have sleep quality that is bad as many as 40 people. Most of female nurse that have children, cause their bad quality of sleep, they should get up in midnight to breastfeeding their children. The others cause that make nurse experience sleep quality that is bad, they experience hot and cold in night. Besides, the bad quality of sleep of nurse also caused by night shift work, some respondent after night shift need minimum 3 days to return normal sleep as usual and when night shift, nurse observe on patient every $2 \mathrm{~h}$ [33].

The related studies explain that sleep has an important thing in recovery process. Overall, nurse that work with rotating shift experience problems such as fatigue, loss of conciousness and sleep disturbance [37]. The research showed that sleep problem is more commonly among shift nurse. Based on this result, this research revealed that shift nurse experience sleep disturbance level that is higher than non-shift nurse $(23.2 \%$ vs. $15.2 \%)$ and shift nurse with sleep disturbance has Sleep plays risk that is bigger [39], [40], [35].

Sleep duration that is $<8 \mathrm{~h}$ related to decrease in work productivity. Especially, sleep duration can be shortened with rest period that is not enough between shift work, which is factors of the increase in Sleep Plays. Thus, the manager of nurse should redesign shift schedule with consider the characteristics of work hours, such long shift, direction and speed of shift rotation, the number of consecutive shift, and rest time among shift, to avoid sleep disturbance, and increase the quality of sleep on shift nurse [38], [42].

The quality of sleep of nurse that is bad tend safety problem (for instance: nursing error) and medical dispute, until related loss cannot be underestimated. Nurse has an important role in physiological, psychological, and social of patient [43]. Nursing job also affect physiological status, psychological, and nurse social [44]. During pandemic of coronavirus disease 2019 (COVID-19), nurse is hoped to work longer hoursșwith more limited rest. Reality, 33\% of nurse in US work longer from $40 \mathrm{~h} /$ week, and 30.5\% seldom or never rest during $30 \mathrm{~min}$ when care the patient of COVID-19 as many as 36 patients. Besides, they also report to experience insomnia, chronic fatigue, acute fatigue, and psychological health problem during pandemic of COVID-19 [36].

The research implication is that to improve the performance of nurses, the hospital management needs to pay attention to and rearrange the performance factors, one of which is the quality of sleep and work stress experienced by nurses and most importantly pay attention to the work of nurses in accordance with the responsibilities and tasks that have been given so that there is no excessive workload on nurses which can reduce the performance of female nurses in hospitals.

\section{Conclusion}

Variables that have a significant effect on work stress are WFC $(X 1)$ with $p<0.05$, while shift work $(X 2)$, nutritional status (X3), and sleep quality (X4) do not have a significant effect on $p>0.05$. Variables that have a significant influence on nurse performance (Y2) are sleep quality $(X 4)$ and work stress $(Y 1)$ with $p<0.05$ while WFC (X1), shift work (X2), and nutritional status (X3) variables have no significant effect with $p>0.05$.

Suggested on female nurses could manage their quality of sleep with rest first before doing the activity, so that when they work, they can work as optimal. Suggestions for further researchers to be able to conduct research at Dr. Hospital Tadjuddin Chalid by further measuring sleep quality using a pulse oximeter sleep care tool to be able to determine sleep quality based on respirator details, SPO2, pulse rate details, sleep details, wake, REM, and deep. In addition, similar researchers can analyze work stress variables using saliva testing for each respondent to determine the 
level of stress that occurs in nurses. So that the factors causing the performance can be known in accordance with the expectations of researchers.

\section{Ethical Statement}

Health Research Ethics Committee, Faculty of Public Health, Hasanuddin University on Date: April 13, 2021 with the number: 2795/ UN4.14.1 TP.02.02/2021

\section{References}

1. Anandyas KR, Mochammad AM. Pengaruh Work-Family Conflict Terhadap Kepuasan Kerja Dan Kinerja (Studi Pada Perawat Wanita Rsud Wonosari Yogyakarta). Jurnal Universitas Brawijaya; 2016. https://doi.org/10.18202/jam23026332.14.3.14

2. Dall'Ora C, Ball J, Recio-Saucedo A, Griffiths P. Characteristics of shift work and their impact on employee performance and wellbeing: A literature review. Int J Nurs Stud. 2016;57:12-27. https://doi.org/10.1016/j.jjurstu.2016.01.007 PMid:27045561

3. Ferri $P$, Guadi M, Marcheselli L, Balduzzi S, Magnani D, Di Lorenzo R. The impact of shift work on the psychological and physical health of nurses in a general hospital: A comparison between rotating night shifts and day shifts. Risk Manag Healthc Policy. 2016;9:203. https://doi.org/10.2147/rmhp.s115326 PMid:27695372

4. Abdalkarem FA, Abuadas $F H$, Hakami MN, Darraj $A A$, Hakami MW. Impact of night shift rotations on nursing performance and patient safety: A cross-sectional study. J Nurs Open. 2021;8(3):1479-88. https://doi.org/10.1002/nop2.766 PMid:33449446

5. Giorgi F, Mattei A, Notarnicola I, Petrucci C, Lancia L. Can sleep quality and burnout affect the job performance of shiftwork nurses? A hospital cross-sectional study. J Adv Nurs. 2018;74(3):698-708. https://doi.org/10.1111/jan.13484 Pmid:29164664

6. Siqueria K, Griep R, Rotenberg L, Silva-Costa A, da Fonseca MD. Weight gain and body mass index following change from daytime to night shift a panel study with nursing professionals. Chronobiol Int. 2016;33(6):776-9. https://doi.org /10.3109/07420528.2016.1167719

Pmid:27159160

7. Kecklund G, Axelsson J. Health consequences of shift work and insufficient sleep. BMJ. 2016;355:i5210. https://doi.org/10.1136/ bmj.i5210

PMid:27803010

8. Lajoie P, Aronson K, Day A, Tranmer J. A cross-sectional study of shift work, sleep quality and cardiometabolic risk in female hospital employees. BMJ Open. 2015;5(3):e007327. https://doi. org/10.1136/bmjopen-2014-007327 PMid:25757950

9. Frone MR. Work-family conflict and employee psychiatric disorders: The national comorbidity survey. J Appl Psychol. 2000;85(6):888-95. https://doi.org/10.1037/0021-9010.85.6.888

\section{PMid:11155895}

10. Ghislieri C, Gatti P, Molino M, Cortese CG. Work family conflict and enrichment in nurse: Between job demands, perceived organisational support and work-family backlash. J Nurs Manag. 2017;25(1):65-75. https://doi.org/10.1111/jonm.12442

11. Zurlo MC, Vallone F, Smith AP. Work-family conflict and psychophysical health conditions of nurses: Gender differences and moderating variables. Jpn J Nurs Sci 2020;17(3):e12324. https://doi.org/10.1111/jjns.12324

12. Nuhu N, Ainuson-Quampah JK, Brown CA, Brown CA Association between caloric intake and work-related stress among nurses in two district hospitals in Ghana. Health Sci Investig (HSI) J. 2020;1(1):50-6. https://doi.org/10.46829/ hsijournal.2020.6.1.1.50-56

13. Li Y, Li XF, Xie L, Shao L, Dong Y. Analytical survey to assess factors associated with sleep quality in registered medical nurses in tertiary first-class hospitals in Shenyang. J Chin Med Univ. 2018;47(7):666-9.

14. Park E, Lee HY, Park CS. Association between sleep quality and nurse productivity among Korean clinical nurses. J Nurs Manag. 2018;26(8):1051-8. https://doi.org/10.1111/ jonm. 12634

PMid:29855101

15. Hughes RG, Rogers AE. Are you tired? Sleep deprivation compromises nurses' health and jeopardizes patients. Am J Nurs. 2004;104(3):36-8. https://doi. org/10.1097/00000446-200403000-00017

16. Wu S, Zhu W, Li H, Wang Z, Wang M. Relationship between job burnout and occupational stress among doctors in China. Stress Health. 2008;24(2):143-9. http://doi.org/10.1002/smi.1169.

17. Song YJ. A Study on the Relationship between the Social Comparison and Career Growth of Nurses in the Thirdgrade Class A Hospital. Nanchang, China: Nanchang University; 2018

18. Lin MD, Ye ML, Peng J, Yin K, Wang Z. The employees' sleep quality: A perspective of organizational behavior. Adv Psychol Sci. 2018;26(6):1096-110.

19. Chin WS, Guo YL, Hung YJ, Yang CY, Shiao JS. Short sleep duration is dose-dependently related to job strain and burnout in nurses: A cross sectional survey. Int J Nurs Stud. 2015;52(1):297-306. https://doi.org/10.1016/j. ijnurstu.2014.09.003

PMid:25311378

20. Muis $M$, Nai'em MF, Arsin AA, Darwis AM, Thamrina $Y$ Hans NA. The effect of multiple role conflicts and work stress on the work performance of female employees. Gac Sanit. 2021;35(S1):S90-3. https://doi.org/10.1016/j. gaceta.2020.12.025 PMid:33832638

21. Diah T. The effect of work family conflict and workload on the performance of female nurses with work stress and emotional exhaustion as an intervening variables on female nurses. Int $\mathrm{J}$ Adv Sci Technol. 2020;29(7):14652-7

22. Kahn RL, Wolfe DM, Quinn RP, Snoek JD, Rosenthal RA Organizational Stress: Studies in Role Conflict and Ambiguity. New York: Wiley; 1964.

23. Saleh ML, Russeng SS, Tadjuddin I. Management Stres Kerja. Yogyakarta: Deepublish Publisher; 2020.

24. Liftyawan, Septina K, Hadi FS, Agustina TS. Effects of workfamily conflict emotional fatigue and job stress on performance. J Penelitian Ipteks. 2020;5(1):1-6.

25. Seguh F, Kolibu FK, Kawatu PA. Relationship between shift work and work stress with nurse performance at Bhayangkara hospital level III Manado. J e-Biomed (eBm). 2019;7(2):4753.

26. Haile KK, Asnakew S, Waja T, Kerbih HB. Shift work sleep disorders and associated factors among nurses at federal 
government hospitals in Ethiopia: A cross-sectional study. Br Med J Open. 2019;9(8):e029802. https://doi.org/10.1136/ bmjopen-2019-029802

27. Liu Q, Shi J, Duan P, Liu B, Li T, Wang C, et al. Is shift work associated with a higher risk of overweight or obesity? A systematic review of observational studies with meta-analysis. Int J Epidemiol. 2018;47(6):1956-71. https://doi.org/10.1093/ije/ dyy079

PMid:29850840

28. Thompson BJ, Stock MS, Banuelas VK. Effects of accumulating shift works on performance-based fatigue using multiple strength measurements in day and night shift nurses and aides. Hum Factors. 2017;59(3):346-56. https://doi. org/10.1177/0018720816677814 PMid:27941163

29. Abdulah DM, Karwan AP, Eleanor $\mathrm{H}$. Fatigue as a primary and secondary factor in relation to shift-rotating and patient safety in nurses. J Hosp Adm. 2019;9(1):1-10.

30. Yamin R, Wahyu A, Ishak H. Effect of BMI, Workload, Work Fatigue, and Complaints of Muskuloskeletal Disorders on Nurse Performance in Sawerigading Hospital Palopo. Amsterdam, Netherlands: Elsevier; 2018. https://doi.org/10.1016/j. enfcli.2019.10.110

31. Björntorp P, Holm G, Rosmond R, Folkow B. Hypertension and the metabolic syndrome: Closely related central origin? Blood Press. 2000;9(2-3):71-82. https://doi. org/10.1080/08037050050151762 PMid:10855728

32. Kalman BA, Grahn RE. Measuring salivary cortisol in the behavioral neuroscience laboratory. J Undergrad Neurosci Educ. 2004;2(2):A41-9.

PMid:23493518

33. Thamrin $Y$, Syahrir P, Darwis M, Putra IS. Relation of body mass index and work posture to musculoskeletal disorders among fishermen. Gac Sanit. 2021;35(Suppl 1):S79-82. https://doi. org/10.1016/j.gaceta.2020.12.022 PMid:33832634

34. Hergenroeder AL, Brach JS, Otto AD, Sparto PJ, Jakicic JM. The influence of body mass index on self-report and performance-based measures of physical function in adult women. Cardiopulm Phys Ther J. 2011;22(3):11-20.

35. Gillet $N$, Huyghebaert-Zouaghi $T$, Réveillère $C$, Colombat $P$, Fouquereau $\mathrm{E}$. The effects of job demands on nurses' burnout and presenteeism through sleep quality and relaxation. J Clin Nurs. 2020;29:583-92. https://doi.org/10.1111/jocn.15116

36. Sagherian K, Clinton ME, Abu-Saad Huijer H, Geiger-Brown J. Fatigue, work schedules, and perceived performance in bedside care nurses. Workplace Health Saf. 2017;65(7):304-12. https:// doi.org/10.1177/2165079916665398

PMid:27872407

37. Uekata S, Kato C, Nagaura $\mathrm{Y}$, Eto $\mathrm{H}$, Kondo $\mathrm{H}$. The impact of rotating work schedules, chronotype, and restless legs syndrome/Willis-Ekbom disease on sleep quality among female hospital nurses and midwives: A cross-sectional survey. Int J Nurs Stud. 2019;95:103-12. https://doi.org/10.1016/j. ijnurstu.2019.04.013 PMid:31129552

38. Sun Q, Ji X, Zhou W, Liu J. Sleep problems in shift nurses: A brief review and recommendations at both individual and institutional levels. J Nurs Manag. 2019;27(1):10-8. https://doi.org/10.1111/ jonm. 12656

PMid:30171641

39. Gingerich SB, Seaverson EL, Anderson DR. Association between sleep and productivity loss among 598676 employees from multiple industries. Am J Health Promot. 2018;32(4):1091 4. https://doi.org/10.1177/0890117117722517 PMid:28823195

40. Kadotani H, Takami M, Nishikawa K, Sumi Y, Nakabayashi T, Fujii $\mathrm{Y}$, et al. Insomnia is associated with presenteeism in Japanese city government employees. Sleep. 2018;41:A136. https://doi.org/10.1093/sleep/zsy061.353

41. Caruso CC. Negative impacts of shiftwork and long work hours. Rehabil Nurs. 2014;39(1):16-25.

PMid:23780784

42. Bambra CL, Whitehead MM, Sowden AJ, Akers J, Petticrew MP. Shifting schedules: The health effects of reorganizing shift work. Am J Prevent Med. 2008;34(5):427-34. https://doi.org/10.1016/j. amepre.2007.12.023 PMid:18407011

43. Yang $\mathrm{H}$, Tang $\mathrm{S}$, Wang $\mathrm{QH}$, Yang J, Cheng $\mathrm{H}$, Cao $\mathrm{HL}$, et al Progress on adverse outcomes of circadian rhythm disorders in nursing staff. Chin Nurs Res. 2019;5:816-21.

44. Anon. National nursing development plan (2016-2020). Chin Nurs Manag. 2017;17(1):15. 